Goldschmidt 2021 Abstract

https://doi.org/10.7185/gold2021.6097

\section{Volcanic ash alteration as driver of (bio-)geochemical iron cycling in deep marine sediments of the Nankai Trough}

\author{
MALE KÖSTER ${ }^{1}$, HAYLEY R. MANNERS ${ }^{2}$, ANETTE \\ MEIXNER $^{3}$, SIMONE A. KASEMANN ${ }^{3}$, MICHAEL \\ STAUBWASSER $^{4}$, YUKI MORONO ${ }^{5}$, FUMIO INAGAKI $^{5}$, \\ VERENA B. HEUER ${ }^{3}$, SABINE KASTEN ${ }^{1,3,6}$ AND SUSANN \\ HENKEL $^{1,3}$ \\ ${ }^{1}$ Alfred Wegener Institute Helmholtz Centre for Polar and \\ Marine Research \\ ${ }^{2}$ School of Geography, Earth and Environmental Sciences, \\ University of Plymouth \\ ${ }^{3}$ MARUM - Center for Marine Environmental Sciences \\ ${ }^{4}$ University of Cologne \\ ${ }^{5}$ JAMSTEC - Japan Agency for Marine-Earth Sciences and \\ Technology \\ ${ }^{6}$ University of Bremen, Faculty of Geosciences \\ Presenting Author: male.koester@awi.de
}

Volcanic ash significantly contributes to marine sediments, especially in regions with active onshore volcanoes. Alteration of volcanic ash releases bicarbonate and cations, which drive precipitation of authigenic carbonate and clay minerals. Furthermore, volcanic ashes are commonly enriched in reactive iron $(\mathrm{Fe}[\mathrm{III}])$, suggesting that ash alteration as a source of reactants plays an important role in (bio-)geochemical processes in marine sediments.

Volcanic ash layers are ubiquitous in sediments of Site C0023, which was established down to $1180 \mathrm{~m}$ below seafloor (mbsf) in the Nankai Trough off Japan during International Ocean Discovery Program Expedition 370. Shipboard measurements show a release of dissolved Fe between 200 and $600 \mathrm{mbsf}$, coinciding with a high abundance of ash layers [1]. The release of $\mathrm{Fe}$ can be related to microbial reduction of structural $\mathrm{Fe}$ (III) in smectite promoting the smectite-to-illite transition, as recently proposed [2]. By combining shipboard pore-water data with sequential extractions of reactive $\mathrm{Fe}$ pools on ash layers and surrounding mud rock and stable $\mathrm{Fe}$ isotope $\left(\delta^{56} \mathrm{Fe}\right)$ analyses, we elucidate the role of ash alteration on (bio-)geochemical cycling at Site $\mathrm{C} 0023$.

Our results demonstrate that reactive Fe(III) is unexpectedly lower in ash layers compared to the surrounding mud rock (0.6 and $1.2 \mathrm{wt} \%$, respectively). This indicates that (1) $\mathrm{Fe}(\mathrm{III})$ originally deposited with tephra has either been used or (2) $\mathrm{Fe}(\mathrm{III})$ in tephra is generally lower due to a different chemical composition in the volcanic source material. The $\delta^{56} \mathrm{Fe}$ signature of hydroxylamine-extracted $\mathrm{Fe}$, which represents easily reducible Fe-oxides and $\mathrm{Fe}$ bound in phyllosilicates, is isotopically light (-0.08 to $-0.42 \%$ ) compared to terrestrial background values ( $\sim 0.09 \%$; [3]). This suggests that this pool is diagenetically overprinted by the precipitation of authigenic smectite formed as a result of ash alteration and/or secondary Fe-oxides. Pore-water $\mathrm{Fe}$ is extremely negative with $\delta^{56} \mathrm{Fe}<-1.5 \%$, which points to microbial reduction of $\mathrm{Fe}(\mathrm{III})$ in authigenic smectite. Our results suggest a coupling between ash alteration, authigenic mineral precipitation, and microbially mediated $\mathrm{Fe}$ reduction in sediments of Site C0023.

[1] Heuer et al., (2017), In Proc. IODP Volume 370.

[2] Kim et al., (2019), Geology 47, 535-539.

[3] Beard et al., (2003), Chem. Geol. 195, 87-117. 